\section{Organic Reactions}

Vol. 9. Edited by Roger Adams, A. H. Blatt, Arthur C. Cope, David Y. Curtin, Frank C. McGrew and Carl Niemann. Pp. viii +468. (New York : John Wiley and Sons, Inc.; London: Chapman and Hall, Ltd., 1957.) 96s. net.

TVERY new volume in this series, which began in 1. 1942, receives a warm welcome from research workers, teachers, and advanced students concerned with reactions capable of wide application in organic chemical synthesis. Many such reactions find repeated mention in text-books and laboratory manuals of organic chemistry; but usually such references are confined to a specific application, give no general survey of the scope of the process concerned, and fail to indicate its limitations, disturbing influences, and variations of practical technique. These omissions are fully met in "Organic Reactions", every volume of which contains a series of chapters each devoted to a single reaction, or sometimes to a definite phase of a reaction, of outstending synthetic importance.

The seven chapters of the present volume, written, as usual, by workers actively engaged in the several fields, deal with the cleavage of non-enolizable ketones with sodium amide, the Gattermann synthesis of aldehydes, the Baeyer-Villiger oxidation of aldehydes and ketones, the alkylation of esters and nitriles, the reaction of halogens with silver salts of carboxylic acids, the synthesis of $\beta$-lactams, and the Pschorr synthesis and related diazonium ring-closure reactions. The account of the alkylation of esters and nitriles is by far the longest of these contributions : discussions of mechanism, scope, methods, and experimental conditions, are supplemented by twenty tabulated summaries giving the alkylating agent, product, yield, and base for an extensive variety of specific esters and nitriles. This chapter alone contains more than a thousand references to the original literature; and, in general, the work is admirably documented and indexed.

JoHN READ

\section{Mathematics and Statistics for use in Pharmacology, Biology and Chemistry}

By L. Saunders and R. Fleming. Pp. $x+257$. (London: The Pharmaceutical Press, 1957. Published by direction of the Council of the Pharmaceutical Society of Great Britain.) 27s. 6d.

TCHE authors have attempted to provide a 1 course adequate for honours students in pharmacy whose mathematical knowledge is slight. Early chapters summarize the elementary rules of indices and logarithms and principles of algebra and graphs. Differential and integral calculus, trigonometry, and differential equations are all oovered within 110 pages. Apart from some carelessness of phrasing, such as describing a determinant as an operator, the text soems sound, though naturally without mathematical rigour. Whether it could in fact be understood by the students for whom it is intended is more doubtful ; it seems more likely to be of service to graduates who have previously studied mathematice more thoroughly but who need a much-condensed revision course.

The second half of the book is concerned with probability and statistics, and is less satisfactory. The text is marred by a number of wrong or misleading statements about populations and samples, expectation, degrees of freedom, and other fundamental ideas. It is difficult to imagine these chapters as adequate even for revision purposes, although the extent of the statistical methods that the authors regard as important for pharmacists is encouraging. The final chapter on quality control and acceptance sampling of pharmaceutical products and errors of dispensing is by far the most interesting in the book; this certainly deserves careful study, and could usefully be developed more fully. D. J. FinNEY

\section{The Support of Medical Research}

Edited by Sir Harold Himsworth and J. F. Delafresnaye. (A Symposium organized by the Council for International Organizations of Medical Sciences.) Pp. xi +170 . (Oxford: Blackwell Scientific Publications, 1956.) 17s. 6 d. net.

THIIS book is a report of a conference which the Council for International Organizations of Medical Sciences held in London late in 1954 under the joint auspices of Unesco and the World Health Organization. The meeting was well attended, and provided the participants with an opportunity for informing each other how research councils and similar institutions operate in their respective countries. It also made possible the statement of views on the desirability of medical research in universities being financed both directly out of university funds and out of subventions from outside bodies, such as the Medical Research Council in Great Britain. The several ways by which central research organizations can support medical research were also discussed, as was the training and recruitment of medical research workers. Appendixes to the book provide brief accounts of the arrangements for medical research which exist in the countries represented at the conference.

\section{Buried Treasure}

By Paul Johnstone. Pp. iii +67 plates. (London : Phoenix House, Ltd., 1957.) 16s. net.

W ${ }^{\text {ITHOUT doubt the television programmes on }}$ W archæology, organized by Paul Johnstone, have much incressed the general interest in the subject. His advisory panel has consisted of experts in the various aspects of the study with the result that viewers have had of the best and not merely secondhand material. The book under review is an account by Johnstone of the various programmes he organized. Piltdown was long supposed to be the earliest human skull found; the exposure created a stir which spread well beyond purely scientific ciroles. It was right that the story of Piltdown and its true significance should be given in the first chapter. But though Piltdown has had to go, there still remains Australopithecus in South Africa, and it is logical that a study of this early creature should follow. The earliest appearance of art and how the artists worked continues the story into late Pleistocene times. Accounts of Jericho, the neolithic stone temples in Malta, Stone Age house building, and the great West Kennet Long Barrow come next; and this leads on to a description of the recent work done at our greatest stone monument of all, Stonehenge. Finally, there are chapters on the Etruscans, on the Gaulish finds at Châtillon-sur-Seine, on Maiden Castle near Dorchester, and on the discoveries made in the Tollund peat bog in Denmark of the well-preserved body of a prehistoric (Iron Age) man. The book is richly illustrated, and there is a short bibliography.

M. C. BURKITT 